\title{
IDENTIFIKASI KETAHANAN PLASMA NUTFAH KARET IRRDB 1981 TERPILIH TERHADAP PENYAKIT GUGUR DAUN CORYNESPORA BERDASARKAN AKTIVITAS TOKSIN CASSIICOLIN
}

\author{
Identification of Resistance of the Selected IRRDB 1981 Rubber Germplasm to \\ Corynespora Leaf Fall Disease Based on Cassiicolin Toxin Activity
}

\author{
Fetrina OKTAVIA $^{\left.{ }^{*}\right)}$, SUDARSONO $^{2)}$, KUSWANHADI $^{11}$, Diny DINARTY ${ }^{2)}$, dan WIDODO ${ }^{3)}$ \\ ${ }^{1}$ Balai Penelitian Sembawa, Pusat Penelitian Karet \\ J1. Raya Palembang - Pangkalan Balai Km. 29, Palembang 30001 Sumatera Selatan \\ Email : fetrina_oktavia@yahoo.com
}

\begin{abstract}
${ }^{2}$ Departemen Agronomi dan Hortikultura, Fakultas Pertanian, Institut Pertanian Bogor, Jl. Meranti, Kampus IPB Dramaga, Bogor, Jawa Barat
\end{abstract} ${ }^{3}$ Departemen Hama dan Penyakit Tanaman, Fakultas Pertanian, Institut Pertanian Bogor
Jl. Meranti, Kampus IPB Dramaga, Bogor, Jawa Barat

Diterima : 13 Maret 2016 / Direvisi : 29 Juli 2016 / Disetujui : 2 Agustus 2016

\begin{abstract}
One of the most important diseases of rubber tree is Corynespora Leaf Fall (CFL) disease, caused by Corynespora cassiicola fungus. The pathogen can attacks in all of rubber plant growth stages, lead to significant decrease of latex production and moreover it is causing plant death. Using resistant clones as a planting material is the most effective and economical way to prevent CLF disease. Therefore identification of resistant clones become the main strategy in the management of CLF disease. This study was aimed to identify the degree of resistance of the 50 selected genotypes IRRDB 1981 (PN'81) germplasm to CLF. The 6 clones of Wickham population were used as a control (BPM 24, BPM 1, GT 1, RRIC 600, PB 260 and RRIM 6OO). Four isolates of C.cassiicola (CC$01, C C-20, C C-22$, and $C C-23)$ were inoculated to young leaves of B2C stage of growth independently, and the intensity of wilting leaves was calculated based on water losses estimation due to the pathogenicderived toxin activity. The results showed that 12 genotypes were highly resistant, 13 genotypes were resistant, 23 genotypes were susceptible and 8 genotypes were highly susceptible. The PN 451, PN 494 and PN 604 genotypes showed better survival rates against CLF compared Wickham population, therefore these genotypes might be potential to be used as a resistant gene source in the rubber breeding program.
\end{abstract}

Keywords: Hevea brasiliensis; Corynespora; Cassicolin; CLF; IRRDB germplasm; toxin; breeding; resistance

Abstrak
Salah satu penyakit pada tanaman
karet adalah penyakit gugur daun
Corynespora (PGDC) yang disebabkan oleh
jamur Corynespora cassiicola. Patogen
tersebut dapat menyerang semua tahap
pertumbuhan tanaman karet yang
menyebabkan terjadinya penurunan hasil
lateks yang cukup signifikan dan bahkan
dapat menyebabkan kematian tanaman.
Penggunaan klon-klon tahan sebagai bahan
tanam merupakan cara yang paling efektif
dan ekonomis untuk mencegah terjadinya
serangan PGDC. Karena itu identifikasi
klon-klon resisten merupakan strategi
utama dalam manajemen PGDC. Penelitian
ini bertujuan untuk mengidentifikasi tingkat
ketahanan 50 genotipe terpilih plasma
nutfah IRRDB 1981 (PN'81) terhadap PGDC.
Enam klon karet yang berasal dari populasi
Wickham digunakan sebagai pembanding
(BPM 24, BPM 1, GT 1, RRIC600, PB 260 dan
RRIM 600). Empat isolat C. cassiicola (CC-
0 1, CC - 20, CC-22, dan CC-2 3)
diinokulasikan masing-masing pada daun
muda tahap pertumbuhan B2C, dan
intensitas kelayuan daun dihitung
berdasarkan estimasi kehilangan air akibat


aktifitas patogenisitas toksin. Hasil penelitian menunjukkan bahwa 12 genotipe tergolong sangat tahan, 13 genotipe tergolong tahan, 23 genotipe tergolong rentan dan 8 genotipe tergolong sangat rentan. Genotipe PN 451, PN 494 dan PN 604 menunjukkan tingkat ketahanan yang lebih baik terhadap PGDC dibandingkan dengan populasi Wickham sehingga ketiga genotipe tersebut berpotensi digunakan sebagai sumber gen ketahanan dalam program pemuliaan tanaman karet.

Kata kunci: Hevea brasiliensis; Corynespora; Cassiicolin; PGDC; plasma nutfah IRRDB; toksin; pemuliaan; ketahanan

\section{PENDAHULUAN}

Tanaman karet (Hevea brasiliensis Muell. Arg) merupakan sumber penghasil karet alam utama yang bernilai ekonomis. Meskipun tanaman tersebut berasal dari Brazil, namun lebih dari 92\% produksi karet alam dunia adalah berasal dari negaranegara di Asia Tenggara. Hal ini terjadi karena hancurnya perkebunan karet di Amerika Latin akibat serangan penyakit gugur daun South American Leaf Blight (SALB) yang menyerang hampir seluruh klon-klon karet yang dibudidayakan saat ini. Sementara di negara-negara penghasil karet alam di luar Amerika, ancaman utama peningkatan produksi lateks adalah Penyakit Gugur Daun Corynespora (PGDC) yang dapat menyerang tanaman pada semua tahap pertumbuhan baik di pembibitan maupun tanaman produksi (Othman, 2013). Penyakit tersebut dapat menyebabkan tanaman mengalami keguguran daun terus menerus yang mengakibatkan terhambatnya pertumbuhan, turunnya produksi lateks, dan dalam kondisi terserang berat dapat menyebabkan kematian tanaman. Di Indonesia, hampir seluruh daerah sentra perkebunan karet terserang PGDC yang mengakibatkan kerugian besar karena penurunan produksi yang mencapai $60 \%$ (Situmorang et al.,2007).

Berbagai upaya pencegahan perkembangan PGDC sudah dilakukan seperti penggunaan pestisida kimiawi dan nabati, jamur antagonis sebagai agen biokontrol (Evueh, Okhuoya, Osemwegie, Attitalla, \& Ogbebor, 2011), atau pengaturan pola tanam dimana dalam suatu areal ditanam berbagai jenis klon (Situmorang et al., 2007). Namun sejauh ini semua metode tersebut masih belum efektif dalam menanggulangi permasalahan PGDC. Penggunaan klon-klon yang memiliki sifat ketahanan yang tinggi dan stabil sebagai bahan tanam merupakan salah satu cara yang paling efektif dan ekonomis dalam mengontrol PGDC. Untuk itu diperlukan identifikasi genotipe-genotipe tahan yang dapat dijadikan sebagai bahan tanam maupun sebagai tetua yang membawa sumber gen ketahanan dalam persilangan.

Selama ini sumber gen ketahanan dalam perakitan genotipe unggul baru masih menggunakan populasi yang berasal dari sejumlah biji yang dibawa oleh Hendry Wickham pada tahun 1876. Populasi yang disebut dengan 'Wickham' tersebut diketahui memiliki dasar genetik yang sempit (Oktavia, Lasminingsih, \& Kuswanhadi, 2011), sehingga penggunaan secara terus menerus dalam persilangan dapat menyebabkan terjadinya erosi genetik atau kepatahan sifat ketahanan. Untuk mengatasi hal tersebut perlu dicari sumber genetik baru, sehingga pada tahun 1981 International Rubber Research Development Board (IRRDB) mengadakan ekspedisi pengumpulan plasma nutfah karet di tiga negara bagian di Brazil yaitu Mato Grosso, Rondonia dan Acre yang merupakan pusat utama keragaman plasma nutfah karet di dunia. Plasma nutfah yang disebut dengan PN IRRDB 1981 atau yang disingkat dengan PN'81 atau plasma nutfah amazon tersebut diduga memiliki keragaman genetik yang tinggi dan membawa berbagai karakter agronomis yang dapat digunakan untuk mengembangkan klon-klon unggul baru.

Kriteria utama dalam pemilihan klon karet unggul adalah produksi lateks yang tinggi. Hal ini menjadi pembatas dalam pemanfaatan PN'81 sebagai klon budidaya, karena dari berbagai pengujian diketahui bahwa populasi tersebut memiliki produksi lateks yang lebih rendah dari populasi Wickham sehingga tidak memungkinkan untuk menggunakanya langsung sebagai klon budidaya. Namun demikian, PN'81 dapat digunakan sebagai sumber genetik berbagai karakter agronomi dalam program 
pemuliaan melalui persilangan. Berbagai penelitian menunjukkan bahwa PN'81 memiliki berbagai karakter agronomi yang baik seperti pertumbuhan yang jagur dan kondisi tajuk daun yang bagus (Aidi-Daslin, 2009; Reghu et al., 2012) kualitas kayu yang baik-(Reghu et al., 2011; Mydin et al., 2012) serta ketahanan terhadap penyakit SALB (Le Guen, Garcia, Mattos, \& Clement-Demange, 2002 ) dan Colletotrichum (Le Guen, Doare, Weber, \& Seguin, 2009). Berdasarkan hal tersebut, PN'81 diduga juga membawa gengen ketahanan terhadap penyakit utama karet lainnya termasuk PGDC.

Informasi ketahanan PN'81 terhadap PGDC sudah dilaporkan oleh Aidi-Daslin, Fairuzah, dan Dalimunthe, (2011). Pada penelitian tersebut sudah dilakukan uji ketahanan 28 geotipe PN'81 terpilih hasil seleksi pertumbuhan dan produksi di Balai Penelitian Sungei Putih terhadap dua isolat C. cassiicola dengan menggunakan metode cakram. Terkait dengan jumlah genotipe PN'81 yang memiliki karakter agronomis baik hasil seleksi di lapangan cukup banyak, maka perlu dilakukan uji resistensi pada genotipe-genotipe tersebut untuk memperbesar kemungkinan memperoleh sumber-sumber gen ketahanan terhadap PGDC. Salah satu cara mengidentifikasi tingkat ketahanan terhadap PGDC adalah berdasarkan aktivitas filtrat toksin yang dihasilkan oleh C. cassiicola. Toksin yang dinamakan dengan Cassiicolin tersebut merupakan faktor kunci utama dalam patogenisitas $C$. cassiicola, sehingga merupakan cara yang tepat untuk melihat reaksi genetik dari tanaman. Selain ituvmetode ini juga dianggap lebih stabil dan tidak dipengaruhi oleh lingkungan (Breton, Sanier, \& d'Auzac, 2000). Dalam penelitian ini dilaporkan potensi genetik ketahanan PN'81 terhadap PGDC berdasarkan aktivitas toksin Cassiicolin.

\section{BAHAN DAN METODE}

Bahan utama yang digunakan dalam penelitian terdiri atas materi tanaman dan sumber isolat $C$. cassiicola. Penelitian dilakukan pada 56 genotipe terpilih sebagai materi genetik yang terdiri dari 50 genotipe PN'81 dan 6 klon dari populasi Wickham (Tabel 1). Genotipe-genotipe tersebut merupakan genotipe terbaik yang memiliki pertumbuhan dan karakter agronomis yang baik dari evaluasi di lapangan. Sumber isolat C. cassiicola yang digunakan dalam percobaan ini adalah CC-01, CC-20, CC-22, dan CC-23 yang diisolasi dari klon karet GT 1, RRIM 600, Tjir 1 dan PR 303 di Kebun Percobaan Balai Penelitian Sembawa, Palembang. Berdasarkan penelitian pendahuluan, keempat isolat tersebut merupakan isolat yang tergolong sangat virulen.

\section{Produksi dan Aplikasi Filtrat Toksin Isolat}

Produksi toksin isolat dilakukan berdasarkan metode Breton et al. (2000) dengan beberapa modifikasi. Uji ketahanan dilakukan di laboratorium berdasarkan aktivitas toksin dari masing-masing isolat $C$. cassiicola dengan menggunakan daun muda berwarna coklat (tahap pertumbuhan B2C). Daun diambil dari lapang dan direndam dalam air selama satu malam (16 jam). Selanjutnya $125 \mathrm{ml}$ toksin (5 mg/L) dimasukan ke dalam baki yang ditutup dengan stryofoam yang dilubangi (diameter 3 $\mathrm{cm}$ ) dan tangkai daun dimasukan ke dalam lubang tersebut sampai terendam filtrat toksin. Sebagai kontrol digunakan air steril sebagai pengganti filtrate toksin dan semua perlakuan diinkubasi pada suhu ruang. Setiap perlakuan diulang sebanyak tiga kali.

\section{Tingkat Ketahanan Genotipe dan Analisis Data}

Tingkat ketahanan diukur berdasarkan estimasi kehilangan air daun akibat aktifitas toksin yang diamati 48 jam setelah perendaman daun dalam filtrate toksin yang diukur sebagai Intensitas Kelayuan Daun (IKD) dengan rumus :

$$
\mathrm{IKD}=\left[\frac{(\mathrm{BB}-\mathrm{BK})}{\mathrm{BK} \text { perlakuan }} \times 100 \%\right]-\left[\frac{(\mathrm{BB}-\mathrm{BK})}{\mathrm{BK} \text { kontrol }} \times 100 \%\right]
$$

$\mathrm{BB}=$ bobot daun sebelum perlakuan toksin $\mathrm{BK}=$ bobot daun setelah perlakuan toksin

Tingkat ketahanan masing-masing genotipe selanjutnya dikelompokkan menjadi 4 yaitu sangat tahan, tahan, rentan dan sangat rentan berdasarkan nilai standar deviasi (SD) dimana kurang dari nilai ratarata -1 SD digolongkan sebagai tanaman 
sangat tahan, -1 SD sampai nilai rata-rata sebagai tanaman tahan, rata-rata sampai +1 SD sebagai tanaman rentan dan lebih dari nilai rata-rata +1 SD digolongkan sebagai tanaman sangat rentan.

Pengelompokan genotipe berdasarkan nilai IKD pada setiap isolat dilakukan dengan metode Hierarki Euclidean menggunakan program DARwin6 (Perrier, Flori, \& Bonnot, 2003). Rancangan yang digunakan dalam penelitian ini adalah Rancangan Acak Lengkap Faktorial. Untuk melihat interaksi antara genotipe dengan isolat dilakukan analisis ANOVA dua faktor (genotipe*isolat) menggunakan program SAS (Statistical Analysis System) dan apabila terdapat perbedaan nyata maka dilanjutkan dengan uji DNMRT (Duncan's Multiple Range Test) $(\mathrm{P}<0,05)$.

\section{HASIL DAN PEMBAHASAN}

\section{Tingkat Ketahanan Genotipe Karet terhadap PGDC}

Salah satu faktor utama yang berperan penting dalam proses patogenisitas isolat C. cassiicola adalah senyawa fitotoksik yang bersifat spesifik inang. Senyawa yang dinamakan dengan Cassiicolin tersebut dapat digunakan sebagai metode seleksi ketahanan tanaman terhadap C. cassiicola (Breton et al., 2000; Deon et al., 2012; Deon et al., 2014). Dibandingkan dengan metode infeksi melalui inokulasi isolat pada daun, metode pengujian melalui toksin lebih bersifat stabil dan sensitifitas terhadap pengaruh lingkungan lebih rendah (Breton et al., 2000) sehingga deteksi ketahanan lebih terfokus ke arah genetik.

Gambar 1 menunjukkan tingkat ketahanan 56 genotipe karet terpilih terhadap 4 toksin isolat $C$. cassiicola yang diuji. Pada gambar tersebut terlihat bahwa tingkat ketahanan suatu genotipe berbeda pada setiap isolat. Namun demikian secara statistik perbedaan isolat tidak memberikan pengaruh nyata terhadap tingkat ketahanan genotipe. Rata-rata IKD semua genotipe pada setiap isolat berkisar 19,29 - 22,62 dengan intensitas tertinggi ditemukan pada isolat CC-01 yang diisolasi dari klon GT 1 (Gambar 2). Hasil ini berbeda dengan penelitian-penelitian sebelumnya yang melaporkan bahwa resistensi tanaman karet terhadap C. cassiicola tergantung kepada genotipe dan isolat yang digunakan, dimana suatu genotipe yang resisten terhadap suatu

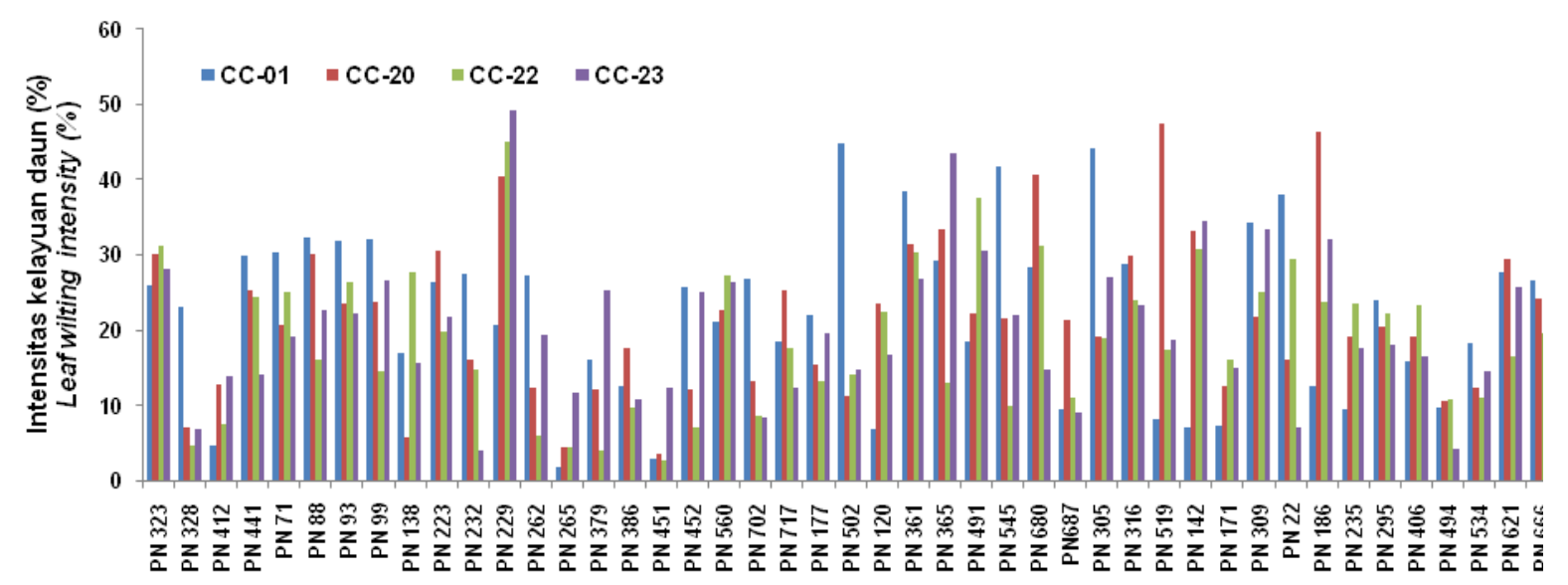

Genotipe karet

Rubbergenotype

Gambar 1. Intensitas Kelayuan Daun (IKD) berbagai genotipe karet terhadap empat isolat $C$. cassiicola. CC-01, CC-20, CC-22 dan CC-23 adalah isolat C. cassiicola yang diisolasi dari klon karet GT 1, RRIM 600, Tjir 1 dan PR 303

Figure 1. Leaf Wilting Intensity of rubber genotypes to four of C. cassiicola isolates. CC-O1, CC20, CC-22 and CC-23 were C. cassiicola isolates that isolated from GT 1, RRIM 600, Tjir 1 and $P R 303$ rubber clones 


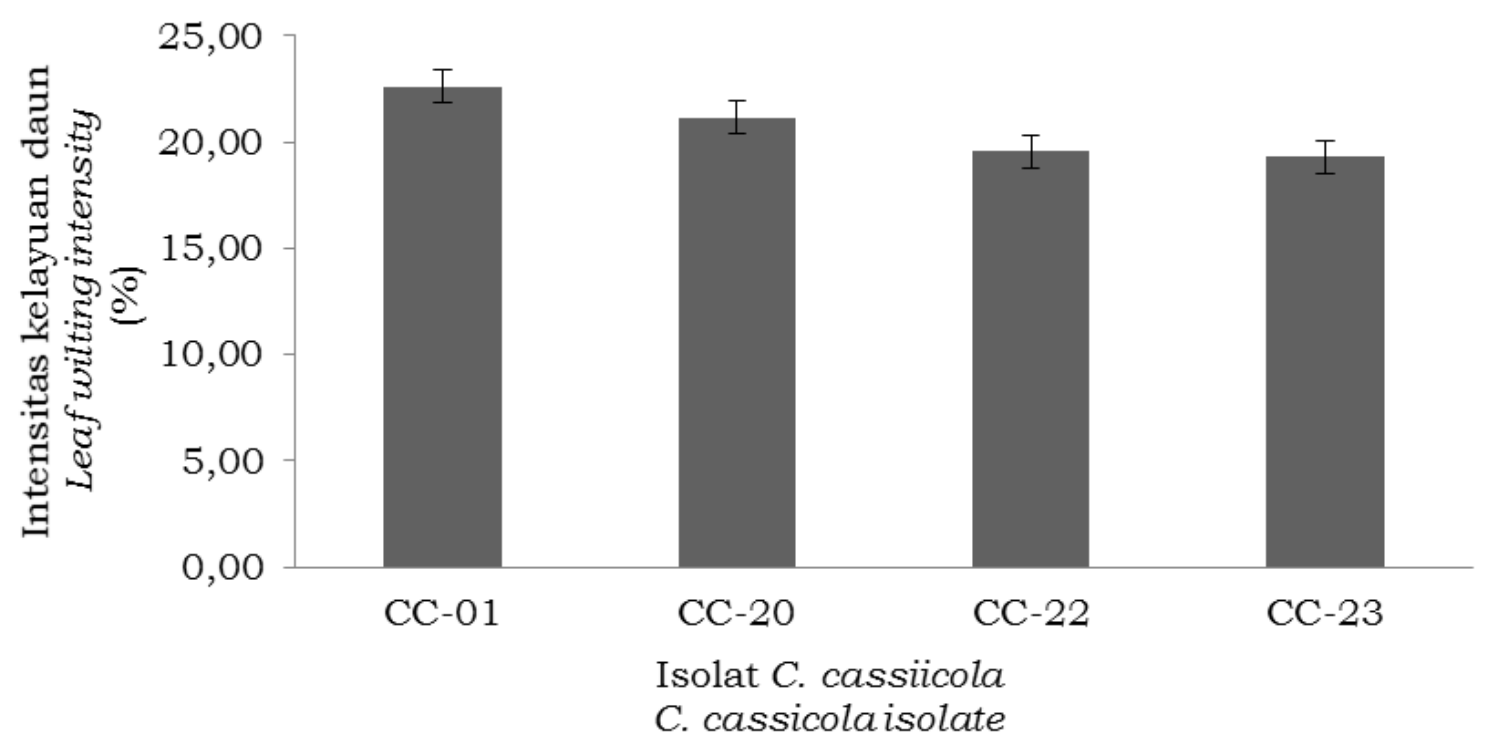

Gambar 2. Rata-rata Intensitas Kelayuan Daun genotipe PN 1981 pada empat isolat $C$. cassiicola. CC-01, CC-20, CC-22 dan CC-23 adalah isolat C. cassiicola yang diisolasi dari klon karet GT 1, RRIM 600, Tjir 1 dan PR 303

Figure 2. Average of leaf Wilting Intensity of the PN 1981 genotypes on the four of C. cassiicola isolates. CC-01, CC-20, CC-22 and CC-23 were C. cassiicola isolates that isolated from GT 1, RRIM 600, Tjir 1 and PR 303 rubber clone

isolat dapat menjadi rentan terhadap isolat lainnya (Situmorang et al., 2007). Namun hal ini dapat dipahami, karena berdasarkan penelitian pendahuluan, semua isolat yang digunakan tergolong kelompok yang sangat virulen sehingga reaksi suatu genotipe terhadap patogenisitas isolat-isolat tersebut diduga juga tidak akan jauh berbeda. Perbedaan reaksi yang nyata mungkin dapat terjadi terhadap isolat-isolat lain yang memiliki tingkat virulensi berbeda.

Menurut Agrios (2005), tingkat ketahanan tanaman terhadap patogen dapat dibedakan atas dua yaitu ketahanan penuh (complete resistance) dan ketahanan parsial (incomplete resistance). Ketahanan penuh adalah kondisi dimana suatu genotipe bersifat sangat tahan terhadap suatu ras isolat (spesifik ras) dan kurang atau tidak tahan terhadap isolat lainnya. Ketahanan ini digolongkan sebagai resistensi vertikal yang dikendalikan secara monogenik. Sedangkan ketahanan parsial merupakan suatu kondisi dimana tingkat ketahanan suatu genotipe relatif sama terhadap semua isolat, sehingga digolongkan sebagai resistensi horizontal yang dikendalikan secara poligenik. Berdasarkan hasil penelitian ini, tingkat ketahanan tanaman karet terhadap PGDC belum dapat dijelaskan apakah tergolong memiliki tingkat ketahanan penuh atau parsial. Namun menurut Tan dan Tan (1996), tingkat ketahanan tanaman karet terhadap PGDC merupakan resistensi horizontal yang dikendalikan oleh banyak gen, sedangkan menurut Hadi, Hartana, dan Sinaga (2004) ketahanan klon karet terhadap PGDC adalah resistensi vertikal yang dikendalikan oleh dua gen utama yang bekerja secara epistasis resesif.

Berdasarkan rata-rata IKD 56 genotipe karet terhadap empat isolat $C$. cassiicola diperoleh nilai rata-rata sebesar 20,64 dan standar deviasi (SD) sebesar 7,63. Nilai tersebut selanjutnya digunakan sebagai dasar pengelompokkan tingkat ketahanan plasma nutfah karet terhadap PGDC, dimana genotipe dengan intensitas kelayuan daun di bawah atau sama dengan rata-rata dikurang standar deviasi yaitu sebesar 13,01\% digolongkan sebagai kelompok genotipe sangat tahan terhadap PGDC, 13,02 - 20,64\% digolongkan sebagai genotipe tahan, 20,65 - 28,27\% digolongkan sebagai kelompok genotipe rentan dan lebih dari $28,27 \%$ sebagai kelompok genotipe sangat rentan. Berdasarkan nilai tersebut, 12 genotipe tanaman karet yang diuji 
Tabel 1. Rata-rata intensitas kelayuan daun dan pengelompokan tingkat resistensi plasma nutfah karet terhadap PGDC

Table 1. Average of leaf wilting intensity and classification of resistance level of rubber germplasm to $C L F$

\begin{tabular}{|c|c|c|c|c|}
\hline $\begin{array}{l}\text { No } \\
\text { No }\end{array}$ & $\begin{array}{l}\text { Genotipe } \\
\text { Genotype }\end{array}$ & $\begin{array}{l}\text { Distrik asal } \\
\text { District origin }\end{array}$ & $\begin{array}{l}\text { Rata-rata IKDa } \\
\text { Average of } L W I \\
(\%)\end{array}$ & $\begin{array}{l}\text { Tingkat ketahanan } \\
\text { Resistance level }^{\mathrm{b}}\end{array}$ \\
\hline 1 & PN 323 & Brasil/RO/A & 28,86 & Sangat Rentan \\
\hline 2 & PN 328 & Brasil/RO/A & 10,43 & Sangat Tahan \\
\hline 3 & PN 412 & Brasil/RO/A & 9,71 & Sangat Tahan \\
\hline 4 & PN 441 & Brasil/RO/A & 23,41 & Rentan \\
\hline 5 & PN 71 & Brasil/RO/C & 23,79 & Rentan \\
\hline 6 & PN 88 & Brasil/RO/C & 25,27 & Rentan \\
\hline 7 & PN 93 & Brasil/RO/C & 26,04 & Rentan \\
\hline 8 & PN 99 & Brasil/RO/C & 24,24 & Rentan \\
\hline 9 & PN 138 & Brasil/RO/C & 16,53 & Tahan \\
\hline 10 & PN 223 & Brasil/RO/C & 24,58 & Rentan \\
\hline 11 & PN 232 & Brasil/RO/C & 15,59 & Tahan \\
\hline 12 & PN 229 & Brasil/RO/C & 38,83 & Sangat Rentan \\
\hline 13 & PN 262 & Brasil/RO/C & 16,23 & Tahan \\
\hline 14 & PN 265 & Brasil/RO/C & 5,61 & Sangat Tahan \\
\hline 15 & PN 379 & Brasil/RO/C & 14,39 & Tahan \\
\hline 16 & PN 386 & Brasil/RO/C & 12,68 & Sangat Tahan \\
\hline 17 & PN 451 & Brasil/RO/C & 4,32 & Sangat Tahan \\
\hline 18 & PN 452 & Brasil/RO/C & 17,52 & Tahan \\
\hline 19 & PN 560 & Brasil/RO/C & 24,31 & Rentan \\
\hline 20 & PN 702 & Brasil/RO/C & 14,29 & Tahan \\
\hline 21 & PN 717 & Brasil/RO/C & 18,40 & Tahan \\
\hline 22 & PN 177 & Brasil/RO/J & 17,51 & Tahan \\
\hline 23 & PN 502 & Brasil/RO/J & 21,23 & Rentan \\
\hline 24 & PN 120 & Brasil/RO/JP & 17,38 & Tahan \\
\hline 25 & PN 361 & Brasil/RO/JP & 31,77 & Sangat Rentan \\
\hline 26 & PN 365 & Brasil/RO/JP & 29,79 & Rentan \\
\hline 27 & PN 491 & Brasil/RO/JP & 27,16 & Rentan \\
\hline 28 & PN 545 & Brasil/RO/JP & 23,77 & Rentan \\
\hline 29 & PN 680 & Brasil/RO/JP & 28,75 & Sangat Rentan \\
\hline 30 & PN687 & Brasil/RO/JP & 12,72 & Sangat Tahan \\
\hline 31 & PN 305 & Brasil/RO/OP & 27,25 & Rentan \\
\hline 32 & PN 316 & Brasil/RO/PB & 26,54 & Rentan \\
\hline 33 & PN 519 & Brasil/RO/PB & 22,87 & Rentan \\
\hline 34 & PN 142 & Brasil/MT/C & 26,35 & Rentan \\
\hline 35 & PN 171 & Brasil/MT/C & 12,68 & Sangat Tahan \\
\hline
\end{tabular}


Lanjutan Tabel 1. Rata-rata intensitas kelayuan daun dan pengelompokan tingkat resistensi plasma nutfah karet terhadap PGDC

Advanced Table 1. Average of leaf wilting intensity and classification of resistance level of rubber germplasm to CLF

\begin{tabular}{lcccc}
36 & PN 309 & Brasil/MT/C & 28,63 & Sangat Rentan \\
37 & PN 22 & Brasil/MT/IT & 22,66 & Rentan \\
38 & PN 186 & Brasil/MT/IT & 28,71 & Sangat Rentan \\
39 & PN 235 & Brasil/MT/IT & 17,44 & Tahan \\
40 & PN 295 & Brasil/MT/IT & 21,17 & Tahan \\
41 & PN 406 & Brasil/MT/IT & 18,70 & Sangat Tahan \\
42 & PN 494 & Brasil/MT/IT & 8,77 & Tahan \\
43 & PN 534 & Brasil/MT/IT & 14,06 & Rentan \\
44 & PN 621 & Brasil/MT/IT & 24,84 & Rentan \\
45 & PN 666 & Brasil/MT/IT & 22,55 & Sangat Tahan \\
46 & PN 667 & Brasil/MT/IT & 10,38 & Rentan \\
47 & PN 725 & Brasil/MT/IT & 31,38 & Rentan \\
48 & PN 261 & Brasil/MT/VB & 22,86 & Sangat Tahan \\
49 & PN 373 & Brasil/AC/F & 24,94 & Rentan \\
50 & PN 604 & Brasil/AC/S & 8,18 & Sangat Tahan \\
51 & BPM 24 & Indonesia & 28,09 & Rentan \\
52 & BPM 1 & Indonesia & 8,96 & Sangat Tahan \\
53 & GT 1 & Indonesia & 28,03 & Tahan \\
54 & RRIC 100 & Sri Lanka & 12,43 & Sangat Rentan \\
55 & PB 260 & Malaysia & 17,55 & 34,48 \\
56 & RRIM 600 & Malaysia & & \\
\hline
\end{tabular}

IKD: Intensitas Kelayuan Daun (LWI: Leaf Wilting Intensity)

${ }^{a}$ Rata-rata berdasarkan nilai IKD genotipe terhadap 4 isolat C.cassiicola

${ }^{a}$ Average based on LWI value of genotype to 4 C. cassiicola isolates

${ }^{\mathrm{b}}$ Pengelompokan tingkat ketahanan genotipe berdasarkan nilai rata-rata IKD terhadap 4 isolat $C$. cassiicola

${ }^{b}$ Classification of genotipe resistance level based on average of LWI to 4 C. cassiicola isolates

merupakan genotipe yang tergolong sangat tahan, 13 genotipe tergolong tahan, 23 genotipe tergolong rentan dan 8 genotipe tergolong sangat rentan terhadap PGDC (Tabel 1).

Dari 50 genotipe PN'81 yang diuji, PN 451 menunjukkan tingkat ketahanan paling tinggi dengan nilai IKD paling rendah yaitu sebesar 4,32\%, sedangkan PN 229 menunjukkan tingkat ketahanan paling rendah dengan nilai IKD tertinggi sebesar $38,83 \%$. Perbedaan kedua genotipe tersebut terlihat pada kondisi daun yang cukup berbeda, dimana pada genotipe rentan (PN 299) terjadi kelayuan daun yang cukup parah serta daun menggulung dan menghitam akibat keracunan toksin sedangkan pada genotipe tahan (PN 451) daun terlihat masih relatif segar dan penggulungan hanya terjadi sedikit pada bagian pinggir daun (Gambar 3).

Perbedaan tingkat ketahanan masing-masing genotipe dipengaruhi oleh mekanisme pertahanan tanaman karet 


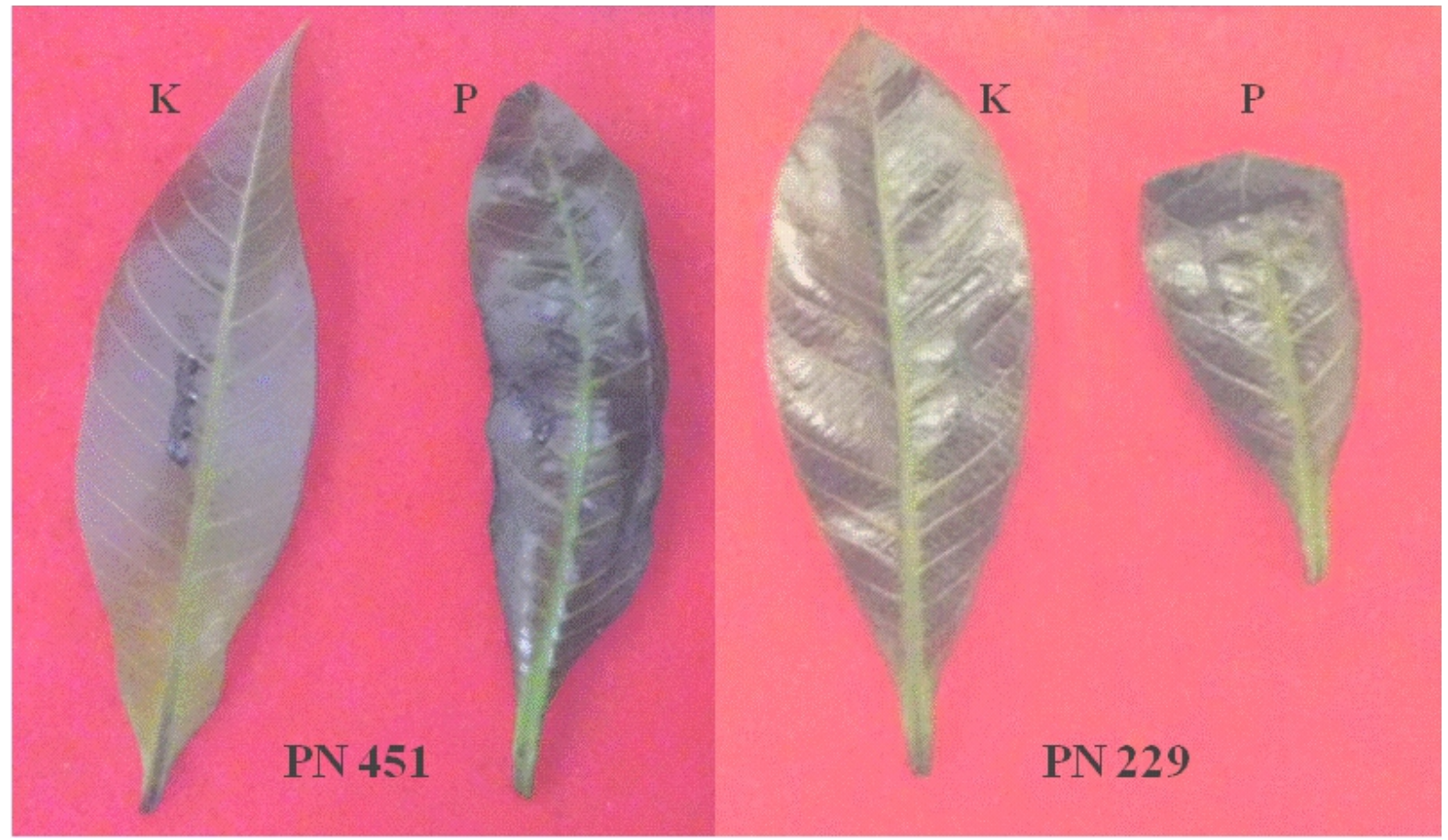

Gambar 3. Perbedaan pengaruh toksin pada genotipe tahan (PN 451) dan rentan (PN 229). Figure 3. Difference of the toxin effect to susceptible (PN 229) and resistant (PN 451) genotypes. Keterangan (Remaks) : K = Kontrol (Control), $\mathrm{P}=$ Perlakuan (Treatment)

terhadap serangan patogen. Secara umum mekanisme pertahanan tanaman karet terhadap penyakit gugur daun seperti $S A L B$, Phytoptora dan Colletotrichum tergantung pada kecepatan pembentukan senyawa fitoaleksin yang disebut dengan skopoletin, dan aktivasi sintesis Pathogenesis RelatedProtein (kitinase dan glukanase) (Churngchow \& Rattarasarn, 2001). Namun berbeda terhadap PGDC, skopoletin tidak dapat dianggap sebagai mekanisme pertahanan utama, karena meskipun terjadi perbedaan produksi skopoletin antara tanaman tahan dan rentan, namun skopoletin yang terbentuk terdegradasi oleh patogen dan dijadikan substrat oleh peroksidase tanaman itu sendiri sehingga tidak efektif memberikan pengaruh fitotoksik terhadap isolat $C$. cassiicola '( Breton, Sanier, d'Auzac, 1997).

Hingga saat ini, mekanisme utama pertahanan tanaman karet terhadap $C$. cassiicola diduga lebih berkaitan erat dengan kepekaan membran sel tanaman terhadap toksin yang dilepaskan patogen pada saat menyerang tanaman. Toksin yang disebut dengan cassiicolin tersebut tergolong Host-Specific Toxins (HST) dimana HST merupakan senyawa utama yang menentukan virulensi pada patogen (Friesen et al., 2008: Oliver \& Solomon, 2010; Horbach et al., 2011) termasuk pada C. cassiicola (Breton et al., 2000; Barthe et al., 2007; Deon et al., 2012; Deon et al., 2014; Pujade-Renaud et al., 2015). Mekanisme kepekaan membran terhadap Cassiicolin terkait dengan kemampuan membran sel menghambat penyerapan toksin dan kemampuan menetralkan toksin yang masuk sehingga tidak berpengaruh terhadap membran sel tanaman. Pada tanaman tahan, terjadi proses penguatan jaringan epidermis melalui proses lignifikasi sehingga dapat menghambat masuk dan menyebarnya toksin melalui tulang daun sedangkan pada tanaman rentan toksin akan masuk dan menyebar dengan cepat (Lazniewska, Macioszek, \& Kononowicz, 2012). Lignifikasi tidak hanya terjadi pada jaringan daun tanaman saja, namun juga terjadi pada hifa C. cassiicola yang sudah masuk pada jaringan tanaman sehingga dapat menghilangkan plastisitas hifa untuk tumbuh (Breton et al., 1997). Pengaruh kandungan lignin pada epidermis terhadap ketahanan tanaman karet juga terlihat pada perbedaan ketahanan daun muda dengan 
daun tua dimana pada daun muda yang kandungan lignin daunnya masih sangat sedikit sehingga sangat mudah terserang PGDC (Atan, Derapi, Ismail, \& Shukor, 2011). Detoksifikasi toksin yang masuk ke jaringan tanaman terjadi melalui reduksi kelompok karbonil penting pada toksin oleh enzim ANDPH-dependent reductase yang diekspresikan oleh tanaman yang tahan sehingga toksin jadi kehilangan kemampuan aktifitasnya. Mekanisme detoksifikasi ini mirip dengan ketahanan berbagai tanaman seperti jagung, padi, sorgum dan tebu terhadap toksin Helmithosporium Carbonum (HC) yang dihasilkan oleh Cochliobolus carbonum (Zainudin et al, 2015), tanaman tembakau terhadap toksin Alternaria Alternate (AAL) yang dihasilkan oleh Alternaria alternata (Tsuge et al., 2013; Zhang et al., 2016) dan tanaman oat terhadap toksin Victorin yang dihasilkan oleh Chocliobolus victoriae (Sweat \& Wolpert, 2007; Sweat et al., 2008).

\section{Pengelompokan Genotipe Karet Berdasarkan Perbedaan Ketahanan Terhadap PGDC}

Analisis Hierarki Euclidean menggunakan program DARwin6 merupakan suatu analisis pengelompokkan berdasarkan perbedaan (dissimilarity) antar genotipe. Gambar 4 menunjukkan dendogram pengelompokan 56 genotipe karet yang diuji. Berdasarkan nilai intensitas kelayuan daun terhadap empat isolat $C$. cassiicola diketahui bahwa beberapa genotipe karet mempunyai perbedaan tingkat ketahanan terhadap PGDC, dimana semakin kecil perbedaan maka semakin dekat hubungan suatu genotipe.

Pada tingkat perbedaan 114, genotipe karet terbagi menjadi dua kelompok besar dan kelompok besar tersebut terbagi lagi menjadi beberapa kelompok kecil. Kelompok besar pertama merupakan kelompok genotipe yang tergolong rentan - sangat rentan terhadap PGDC. Pada kelompok besar pertama tersebut, genotipe PN 71 dan PN 93 memiliki perbedaan yang paling kecil, atau dengan kata lain kedua genotipe tersebut memiliki tingkat kerentanan yang paling dekat. Namun sebaliknya dengan kelompok besar kedua, genotipe yang tergolong pada kelompok tersebut adalah genotipe yang tergolong tahan - sangat tahan terhadap PGDC. Pada kelompok tersebut, genotipe PN 265 dan 534 merupakan genotipe yang memiliki tingkat ketahanan yang paling dekat. Dendogram juga menunjukkan bahwa pengelompokan yang terbentuk tidak menunjukkan daerah asal dari genotipe tersebut. Hal ini menunjukkan bahwa potensi genotipe-genotipe yang tahan terhadap PGDC tersebar pada semua daerah asal plasma nutfah karet.

\section{Struktur Resistensi Populasi}

Analisis pada masing-masing distrik menunjukkan bahwa tingkat ketahanan genotipe pada semua distrik terlihat heterogen. Tingkat ketahanan tertinggi diantara distrik ditemukan pada populasi asal Sena Madureira (AC/S), demikian juga pada tingkat populasi yang lebih besar tingkat ketahanan tertinggi secara umum ditemukan pada genotipe yang berasal dari Acre, sedangkan persentase ketahanan terendah ditemukan pada populasi yang berasal dari Rondonia (Tabel 2). Hal ini menunjukkan bahwa populasi asal Distrik Acre berpotensi membawa sumber gen ketahanan terhadap PGDC dibandingkan dengan populasi asal Mato Grosso dan Rondonia. Namun hal ini masih merupakan dugaan karena jumlah populasi asal Acre yang dianalisis masih terbatas sehingga perlu konfirmasi dengan jumlah populasi yang lebih banyak. Hal ini juga berbeda dengan yang ditemukan pada analisis ketahanan plasma nutfah karet terhadap penyakit gugur daun $S A L B$ (Le Guen et al., 2002) dan Colletotrichum (Le Guen et al., 2009), dimana genotipe yang berasal dari Rondonia memiliki tingkat ketahanan lebih tinggi dibanding genotipe asal daerah lainnya dan genotipe asal Mato Grosso merupakan genotipe yang paling rentan.

Uji ketahanan menunjukkan bahwa PN'81 memiliki potensi ketahanan yang lebih baik dari klon-klon Wickham, 


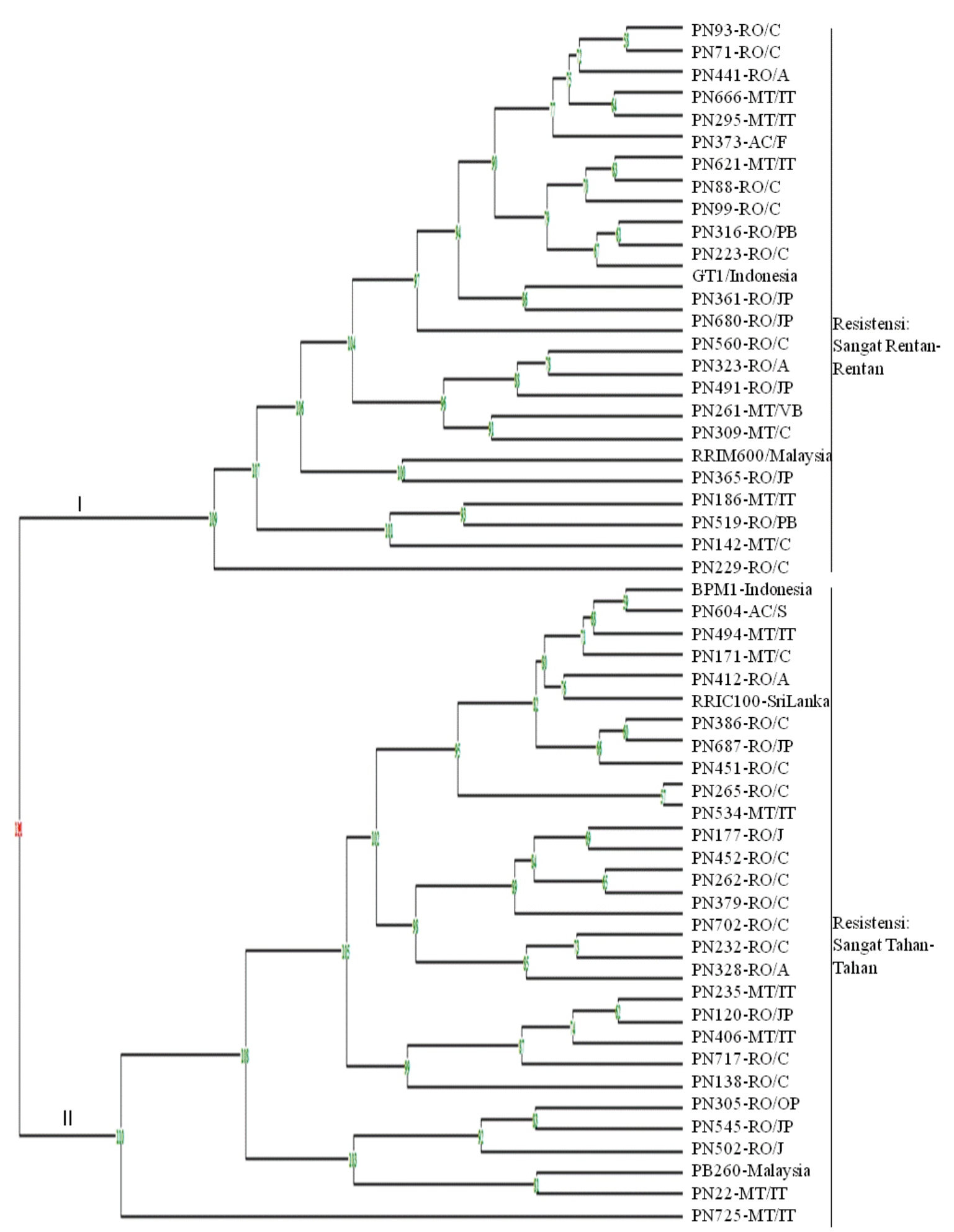

Gambar 4. Dendogram pengelompokan plasma nutfah karet berdasarkan tingkat ketahanan terhadap PGDC dengan metode Hierarki Euclidean

Figure 4. Clustering dendogram of the rubber germplasm based on resistance level to CLF using the Euclidean Hierarchy method 
Tabel 2. Persentase genotipe tahan dari masing-masing daerah asal plasma nutfah karet Table 2. Percentage of the resistant genotypes from each origin of rubber germplasm

\begin{tabular}{|c|c|c|c|c|}
\hline $\begin{array}{l}\text { Negara } \\
\text { b agian asal } \\
\text { Origin of } \\
\text { Country }\end{array}$ & $\begin{array}{l}\text { Distrik asal } \\
\text { Origin of } \\
\text { District }\end{array}$ & $\begin{array}{l}\text { Singkatan } \\
\text { Abbreviation }\end{array}$ & $\begin{array}{c}\text { Jumlah genotipe } \\
\text { yang dianalisis } \\
\text { Number of } \\
\text { analyzed } \\
\text { genotypes } \\
\end{array}$ & $\begin{array}{c}\text { Jumlah genotipe tahan } \\
\text { Number of resistant } \\
\text { genotypes } \\
(\%)\end{array}$ \\
\hline \multirow{7}{*}{ Rondonia } & \multirow{3}{*}{$\begin{array}{l}\text { Ariquemes } \\
\text { Calama } \\
\text { Jaru }\end{array}$} & $\mathrm{RO} / \mathrm{A}$ & 4 & $2(50)$ \\
\hline & & $\mathrm{RO} / \mathrm{C}$ & 17 & $3(17,6)$ \\
\hline & & $\mathrm{RO} / \mathrm{J}$ & 2 & 0 \\
\hline & \multirow{2}{*}{$\begin{array}{l}\text { Jiparana } \\
\text { Ouro Preto }\end{array}$} & $\mathrm{RO} / \mathrm{JP}$ & 7 & $1(14,3)$ \\
\hline & & $\mathrm{RO} / \mathrm{OP}$ & 1 & $0(0)$ \\
\hline & \multirow[t]{2}{*}{$\begin{array}{l}\text { Pimenta } \\
\text { Bueno }\end{array}$} & $\mathrm{RO} / \mathrm{PB}$ & 2 & $0(0)$ \\
\hline & & Total & 33 & $6(18,2)$ \\
\hline \multirow{4}{*}{$\begin{array}{l}\text { Mato } \\
\text { Grosso }\end{array}$} & \multirow{4}{*}{$\begin{array}{l}\text { Cartriquacu } \\
\text { Itauba } \\
\text { Vila Bela }\end{array}$} & $\mathrm{MT} / \mathrm{C}$ & 3 & $1(33,3)$ \\
\hline & & $\mathrm{MT} / \mathrm{IT}$ & 11 & $2(18,2)$ \\
\hline & & $\mathrm{MT} / \mathrm{VB}$ & 1 & 0 \\
\hline & & Total & 15 & $3(20)$ \\
\hline \multirow{3}{*}{ Acre } & Feijo & $\mathrm{AC} / \mathrm{F}$ & 1 & $0(0)$ \\
\hline & $\begin{array}{l}\text { Sena } \\
\text { Madureira }\end{array}$ & $\mathrm{AC} / \mathrm{S}$ & 1 & $1(100)$ \\
\hline & & Total & 2 & $1(50)$ \\
\hline Wickham & Boim & W & 6 & $2(33,3)$ \\
\hline
\end{tabular}

dimana 3 di antara genotipe yang tergolong tahan memiliki tingkat ketahanan di atas klon Wickham BPM 1 yaitu PN 451 yang berasal dari RO/C, PN 494 dari MT/IT dan PN 604 dari AC/S. Ketiga genotipe tersebut berpotensi digunakan sebagai sumber gen ketahanan dalam program pemuliaan tanaman karet karena berasal dari sumber genetik yang lebih luas sehingga diharapkan dapat menghasilkan genotipe-genotipe unggul yang lebih baik.

\section{KESIMPULAN}

Analisis ketahanan 56 genotipe karet terhadap PGDC menunjukkan bahwa terdapat perbedaan tingkat ketahanan antar genotipe, namun secara statistik tingkat ketahanan genotipe terhadap masingmasing isolat tidak berbeda. Berdasarkan rata-rata ketahanan terhadap empat isolat C. cassiicola diperoleh 12 genotipe sangat tahan, 13 genotipe tahan, 23 genotipe 
rentan dan 8 genotipe sangat rentan. Tiga di antara genotipe $\mathrm{PN}^{\prime} 81$ yang tergolong sangat tahan yaitu PN 451, PN 494 dan PN 604 memiliki tingkat ketahanan yang lebih baik dari klon pembanding BPM 1 yang berasal dari populasi Wickham. Ketiga genotipe tersebut diharapkan dapat digunakan sebagai sumber gen ketahanan terhadap PGDC melalui persilangan buatan.

\section{DAFTAR PUSTAKA}

Agrios, G. N. (2005). Plant Pathology Fifth Edition. Boston, USA: Elsevier Academic Press.

Aidi-Daslin. (2009). Genotipe terpilih sebagai penghasil kayu lateks dari plasma nutfah karet IRRDB 1981. Dalam N. Siagian, C. Anwar, A. Gunawan, \& A. Rachmawan. Prospek dan pengembangan kayu karet (pp. 75-84). Medan, Indonesia: Pusat Penelitian Karet.

Aidi-Daslin., Fairuzah, Z., \& Dalimunthe, C. (2011). Uji resistensi genotipe terpilih dari plasma nutfah IRRDB terhadap penyakit gugur daun Corynespora dengan metode cakram daun. Jurnal Penelitian Karet, 29(1), 16-24.

Atan, S., Derapi, S., Ismail, L., \& Shukor, N. (2011). Screening susceptibility of Hevea progenies from PB 5/51 x IAN 873 to two races of Corynespora cassiicola. J. Rubb. Res., 14(2), 110122.

Barthe, P., Pujade-Renaud, V., Breton, F., Gargani, D., Thai, R., Roumestand, C., \& Lamotte, F. (2007). Structural analysis of cassiicolin, a host-selective protein toxin from Corynespora cassiicola. J. Mol. Biol., 367(1), 89-101. Doi: 10.1016/j.jmb.2006.11.086.

Breton, F., Sanier, C., \& d'Auzac, J. (1997). Scopoletin production and degradation in relation to resistance of Hevea brasiliensis to Corynespora cassiicola. Journal of Plant Physiology, 151(5), 595-602. Doi: 10.1016/S01761617(97)80236-2.
Breton, F., Sanier, C., \& d'Auzac, J. (2000). Role of cassiicolin a host-selective toxin in pathogenicity of Corynespora cassiicola causal agent of a leaf fall disease of Hevea. J. Rubb. Res., 3(2), 115-128.

Churngchow, N., \& Rattarasarn, M. (2001). Biosynthesis of scopoletin in Hevea brasiliensis leaves inoculated with Phytophthora palmivora. J Plant Physiol, 158, 875-882. Doi: 10.1078/0176-1617-00230.

Déon, M., Bourré, Y., Gimenez, S., Berger, A., Bieysse, D., de Lamotte, F., Poncet, J., Roussel, V., Bonnot, F., \& Oliver, G. (2012). Characterization of a cassiicolin-encoding gene from Corynespora cassiicola, pathogen of rubber tree (Hevea brasiliensis). Plant Science, 185-186, 227-237. Doi: 10.1016/j.plantsci.2011.10.017.

Déon, M., Fumanal, B., Gimenez, S., Bieysse, D., Oliveira, R. R., Shuib, S. S., Breton, F., Elumalai, S., Vida, J. B., \& Seguin, M. (2014). Diversity of the cassiicolin gene in Corynespora cassiicola and relation with the pathogenicity in Hevea brasiliensis. Fungal Biology, $118(1), 32-47$. D o i: 10.1016/j.funbio.2013.10.011.

Evueh, A., Okhuoya, J., Osemwegie, O., Attitalla, I., \& Ogbebor, O. (2011). Evaluation of phylloplane fungi as biocontrol agent of Corynespora leaf fall disease of rubber (Hevea brasiliensis Muell. Arg.). World J. Fungal Plant Biology, 2(1), 1-5.

Friesen, T. L., Faris, J. D., Solomon, P. S., \& Oliver, R. P. (2008). Host-specific toxins: effectors of necrotrophic pathogenicity. Cell. Microb., 10(7), 1421-1428. Doi: 10.1111/j.14625822.2008.01153.x.

Hadi, H., Hartana, A., \& Sinaga, M. (2004). Analisis genetika pewarisan sifat ketahanan tanaman karet terhadap penyakit gugur daun Corynespora. Hayati, 11(1), 1-5. 
Horbach, R., Navarro-Quesada, A. R., Knogge, W., \& Deising, H. B. (2011). When and how to kill a plant cell: infection strategies of plant pathogenic fungi. J. Plant Physiol. 168(1), 51-62. Doi: $10.1016 / j . j p l p h .2010 .06 .014$.

Lazniewska, J., Macioszek, V. K. \& Kononowicz. (2012). Plant-fungus interface: the role of surface structures in plant resistance and susceptibility to pathogenic fungi. Phys. Mol. Pant Pathol., 78, 24-30.

Le Guen, V., Doaré, F., Weber, C., \& Seguin, M. (2009). Genetic structure of amazonian populations of Hevea brasiliensis is shaped by hydrographical network and isolation by distance. Tree Genetics \& Genomes, 5(4), 673-683. Doi: 10.1007/s11295009-0218-9.

Le Guen, V., Garcia, D., Mattos, C. R. R., \& Clément-Demange, A. (2002). Evaluation of field resistance to Microcyclus ulei of a collection of Amazonian rubber tree (Hevea brasiliensis) germplasm. Crop Breeding and Applied Biotechnology, 2(1), 141-148. Doi: 1012702/19847033.v02n01a18.

Mydin, K., Narayanan, C., \& Abraham, T. (2012). Incorporation of the 1981 IRRDB wild amazonian germplasm in Hevea breeding in India. IRRI-IRRDB Rubber Plant Breeding Seminar (15 p.). Medan, Indonesia: IRRI-IRRDB.

Oktavia, F., Lasminingsih, M., \& Kuswanhadi. (2011). Genetic Relationship of Wickham and IRRDB 1981 Rubber Population Based on RAPD Markers Analysis. HAYATI. Journal of Biosciences, 18(1), 27-32. Doi: $10.4308 /$ hjb.18.1.27

Oliver, R. P., \& Solomon, P. S. (2010). New developments in pathogenicity and virulence of necrotrops. Curr. Op. Plant Biol. $13,415-419$. D o i : 10.1016/j.pbi.2010.05.003.
Othman, R. (2013). Development of high yielding disease resistance clones. IRRDB Agronomy Workshop. Medan, Indonesia : IRRI-IRRDB.

Perrier, X., Flori, A., \& Bonnot, F. (2003). Data analysis methods. In P. Hamon, M. Sequin. X. P. Perrier., \& J. C. Glaszmann. Genetic diversity of cultivated tropical plants (pp.43-76). Montpellier, France: Enfield Science Publisher.

Pujade-Renaud, V., Lopez, D., Ribeiro, S., Minh, T., Deon, M., Clement-Demange, A., Garcia, D., Drevet, P., Label, P., \& Morin, E. (2015). The effectors of Corynespora cassiicola virulence in rubber tree. Proceedings of International Rubber Confrence (pp. 221-224). Ho Chi Minh, Vietnam: RRIV-IRRDB.

Reghu, C., Prabhakara, G., \& Mercy, M. (2011). Progress and future strategies of the breeding programme involving the 1981 IRRDB hevea germplasm collection in India. RRIT-IRRDB Plant Breeding Seminar. Koh Samui, Thailand: RRIT-IRRDB.

Reghu, P., Mercy, M., \& Lakshmanan, R. (2012). Further evaluation and selection of 1981 IRRDB wild Hevea germplasm collection in India. Nat. Rubb. Res., 25(1), 31-38.

Situmorang, A., Sinaga, M., Suseno, R., Hidayat, S., Siswanto, \& Darussamin, A. (2007). Sebaran penyakit gugur daun corynespora di sentra perkebunan karet Indonesia. Jurnal Penelitian Karet, 25(1), 76-82.

Sweat, T. A., \& Wolpert, T. (2007). Thioredoxin h5 is required for victorin sensitivity mediated by a CC-NBS-LRR gene in Arabidopsis. Plant Cell, 19(2), $673-687$. D o i : $10.1105 /$ tpc. 106.047563 . 
Sweat, T. A., Lorang, J. M., Bakker, E. G., \& Wolpert, T. J. (2008). Characterization of natural and induced variation in LOV1 gene, a CC-NB-LRR gene conferring victorin sensitivity and disease susceptibility in Arabidopsis. Mol. Plant-Microbe. Interact., 21(1), 719. Doi: 10.1094/MPMI-21-1-0007.

Tan, A., \& Tan, A. (1996). Genetic studies of leaf diseases resistance in Hevea. $J$. Nat. Rubb. Res., 11(2), 108-114.

Tsuge, T., Harimoto, Y., Akimitsu, K., Ohtani, K., Kodama, M., Akagi, Y., Egusa, M., Yamamoto, M., \& Otani, H. (2013). Host-selective toxins produced by the plant pathogenic fungus Alternaria alternata. FEMS Microbiol. Rev., 37(1), 44-66. Doi: 10.1111/j.1574-6976.2012.00350.x.
Zainudin, N. A. I. M., Condon, B., Bruyne, L. D., Poucke, C. V., Bi, Q., Li, W., Hofte, M., \& Turgeon, B. G. (2015). Virulence, Host-Selective Toxin Production, and Development of Three Cochliobolus Phytopathogens Lacking the Sfp-Type 4'-Phosphopantetheinyl Transferase Ppt1. Mol. Plant-Microbe. Interact., 28(10), $1130-1141$. Doi : 10.1094/MPMI-03-15-0068-R.

Zhang, M., Koh, J., Liu, L., Shao, Z., Liu, h., Hu, S., Zhu, N., Dufresne, C. P., Chen, S., \& Wang, Q. (2016). Critical Role of COI1-Dependent Jasmonate Pathway in AAL toxin induced PCD in Tomato Revealed by Comparative Proteomics. Sci. Rep., 6 (28451). DOI: $10.1038 /$ srep28451. 